\title{
Artigo
}

\section{Processos de governo no presidencialismo brasileiro: a estrutura de coordenação política da Presidência}

\author{
The government decision making process in the \\ Brazilian presidentialism: the political coordination \\ arrangements of the presidency
}

\section{Camila Romero Lameirão}

Coordenadora do Curso de Especialização em Políticas Públicas, Professora adjunta, Universidade Federal de Goiás (UFG), Goiânia, GO, Brasil cromero.cp@gmail.com

Resumo: Os processos de governo, ou a produção de decisões, no presidencialismo brasileiro envolvem além da arena legislativa, a participação de atores e estruturas do poder Executivo, que operam no assessoramento e na articulação do exercício governamental. Com base neste entendimento, o artigo pretende explorar uma perspectiva de análise que enfoque as dinâmicas de atuação interna do Executivo, principalmente avaliando as diferenças e continuidades que podem emergir de um governo para outro, de forma a entender como os presidentes se "equipam" para governar. Para tanto, será enfatizada a estrutura de coordenação política da Presidência. Este trabalho considera que no presidencialismo de coalizão o chefe do Executivo constitui-se, do ponto de vista institucional, o ator central (o pivô) tanto para montagem e incentivos ao exercício de uma coalizão, como nos processos de decisão política que ocorre no Legislativo e, por isso, há que se investigar como é conduzido, então, o relacionamento com o Legislativo sob a ótica do Executivo. Com este propósito, poder-se-á iniciar uma reflexão sobre o papel do presidente, em geral, e da Presidência, em particular, para o funcionamento do presidencialismo brasileiro.

Palavras-chave: Processos de governo; Presidencialismo; Executivo; Presidência; Coordenação política; Coalizão. 


\begin{abstract}
The government policy making process, or decision making process, under Brazilian presidentialism includes beyond the legislative arena, the participation of actors and structures from Executive branch, that work in the advisory and articulation of the government. Based on this understanding, the paper aims to explore an analytical approach that emphasize the Executive branch and its internal dynamics of work, mainly evaluating the differences and continuities that can arise from one administration to another in order to understand how the presidents design their staff to exercise the government. Therefore, this article will emphasize the arrangement of political coordination of the presidency. This study considers that in the coalitional presidentialism the chief of the Executive is, from an institutional point of view, the leading actor (the pivotal role) both to build and to incite the work of the coalition, and also in the policy making process that occur in the Legislative branch, that is why the relationship with Congress should be investigated from an Executive approach. Considering this purpose, maybe, will be possible to begin a reflection about the role of the president in general, and the presidency in particular, to the work of the Brazilian presidentialism.
\end{abstract}

Keywords: Government policy making process; Presidentialism; Executive branch; Presidency; Political coordination; Coalition.

\title{
Introdução
}

Os estudos sobre processos de governo no Brasil, sejam no âmbito federal, estadual ou municipal, costumam levar em conta, predominantemente, a relação entre Executivo e Legislativo como forma de avaliar a capacidade de um governo tomar decisões (ANDRADE, 1998; NICOLAU, 2000; SANTOS, 1999; AMORIM NETO, 2000; AMORIM NETO; SANTOS, 2001; FIGUEIREDO; LIMONGI, 2001; MELO; ANASTASIA, 2005). Inclusive, ao analisarem os atores e mecanismos institucionais que mediam a relação entre esses dois poderes, tendem a identificá-los na arena legislativa, isto é, apontam os líderes do governo no Congresso Nacional, assim como o "Colégio de Líderes", a "Mesa Diretora" e as "Comissões Parlamentares" como canais pelos quais transcorrem processos de negociação e articulação que viabilizam a governabilidade.

Essa perspectiva, embora producente, não dá conta de toda a complexidade que envolve os processos de governo do Executivo, que no curso da tomada de decisão também dependem de atores e canais internos que assessorem e articulem as decisões governamentais. Sendo assim, é oportuno o desenvolvimento de uma agenda de pesquisa que enfatize as dinâmicas de atuação interna do Executivo, principalmente avaliando as diferenças e continuidades que podem emergir de um governo para outro, de forma a entender como os presidentes se "equipam" para governar e os espaços de negociação e decisão que privilegiam. 
O presente trabalho pretende contribuir para esse campo de pesquisa, produzindo uma investigação que enfatize a estrutura de poder que cerca o presidente da República', mais especificamente os atores e canais institucionais que se vinculam diretamente ao chefe de governo. Neste caso, a ênfase recairá sobre a estrutura de coordenação política da Presidência. Com este propósito, poder-se-á iniciar uma reflexão sobre o papel do presidente, em geral, e da Presidência da República, em particular, para o funcionamento do presidencialismo de coalizão.

Precisamente, concebendo que no presidencialismo brasileiro o chefe do Executivo constitua, do ponto de vista institucional, o ator preponderante (o pivô) tanto para montagem e incentivos ao exercício de uma coalizão, como nos processos de decisão política que ocorre no Legislativo - pelas seguintes razões: i) parte dele a iniciativa e autorização para compor alianças partidárias, dado o interesse em alcançar maioria parlamentar; ii) detém, constitucionalmente, o controle dos recursos (cargos e emendas orçamentárias) que mobilizam os partidos políticos a aderir à base governamental; e, por fim, iii) é provido de poderes de agenda², ou legislativos, constitucionalmente estabelecidos, pelos quais detém a prerrogativa de iniciar e influenciar o processo legislativo ${ }^{3}$-, há de se investigar como é conduzido, então, o relacionamento com o Legislativo sob a ótica do Executivo.

É válido notar que, sob esta perspectiva, a ciência política brasileira com o objetivo de compreender o comportamento institucional do presidente da República em relação ao sistema político, notadamente na interação com o Congresso Nacional, vem investindo em estudos sobre os poderes de agenda, ou legislativos, exclusivos do poder Executivo (FIGUEIREDO; LIMONGI, 1997; SANTOS, 1997; PESSANHA, 1997; PEREIRA; MUELLER, 2000; AMORIM NETO; TAFNER, 2002). Pode-se considerar que as análises acerca dos poderes

1 Este trabalho considera a distinção organizacional que divide o Poder Executivo entre o núcleo diretamente ligado à presidência e os ministérios e secretarias de Estado. Por exemplo, no atual governo, de Michel Temer (2016- ), os órgãos que compõem a presidência da República são: Casa Civil, Secretaria de Governo, Gabinete Pessoal, Gabinete de Segurança Institucional e Secretaria Geral, conforme os termos da Lei no 13.266 de 2016 e da Media Provisória no 768 de 2017.

2 Conforme os Artigos $61\left(\S 1^{\circ}\right)$, 62 e 84 (incisos V e VI) da CF/1988, os poderes de agenda do presidente brasileiro consistem na: i) iniciativa exclusiva de leis; ii) solicitação de urgência no trâmite de legislação no Congresso Nacional com a edição de medidas provisórias (MP); iii) poder de veto; e iv) edição de decretos.

3 Amorim Neto e Tafner (2002, p. 21) ressaltam que ".... a alta taxa de reedição de MPs pode ser entendida como o resultado não da passividade, incapacidade ou desinteresse do Congresso em apreciá-las, mas, sim, como consequência de uma escolha racional da maioria parlamentar no que concerne à maneira mais eficaz de obter informações sobre seus efeitos". Isto significa que os parlamentares optam estrategicamente por retardar a apreciação sobre uma medida provisória para avaliar seus resultados e deixar ao Executivo o ônus de suas consequências. Nesta interpretação, a prerrogativa de editar MPs por parte do presidente não exclui automaticamente os parlamentares e partidos de sua apreciação no Congresso. 
legislativos do presidente são o que há de mais próximo à compreensão da atuação do Executivo no sistema político brasileiro.

Este trabalho pretende ir além das referências que enfatizam os recursos institucionais exclusivos do presidente, propondo-se a analisar outras variáveis envolvidas nas relações entre Executivo e Legislativo. Nesta direção, pretende-se investigar a Presidência da República e avaliar de que forma o presidente organiza sua estrutura de poder em vista a necessidade de se relacionar com o Congresso Nacional e, em termos específicos, com os partidos políticos que constituem a coalizão.

O texto está dividido em quatro seções, além desta introdução e da conclusão, na forma de apontamentos finais. A seguir serão discutidas as referências teóricas que sustentam o estudo em curso, destacando como se processam as decisões do governo no sistema presidencial de separação de poderes e o papel institucional da presidência. Na seção seguinte haverá uma breve exposição sobre as interpretações de como funciona o presidencialismo sob um contexto multipartidário e fragmentado, como é o caso brasileiro, considerando, ainda, as discussões mais recentes que enfatizam a preponderância do Executivo no processo legislativo. Em seguida, na terceira seção, far-se-á uma descrição a respeito do arranjo da Presidência dedicado à coordenação política governamental, responsável, em tese, por tratar dos assuntos parlamentares que envolvem a gestão do governo. Por fim, na quarta seção, haverá uma breve apresentação sobre algumas medidas elaboradas para aferir o nível e o tipo de supostos movimentos de descentralização do arranjo de coordenação política da Presidência no decorrer das gestões de FHC e Lula. Os apontamentos finais deste trabalho pretendem sistematizar algumas conclusões sobre as reformas observadas nas estruturas de coordenação política dos dois governos.

\section{Relação entre os poderes e o papel da Presidência: como se governa?}

Os estudos sobre processos de governo desenvolvidos pela ciência política brasileira centram-se, majoritariamente, no segmento legislativo do processo decisório, abordando apenas indiretamente o segmento pré-legislativo, em que decisões são formuladas, negociadas e coordenadas no âmbito do poder Executivo (ANDRADE, 
1998). Sabe-se pouco a respeito dos processos pelos quais são produzidas decisões no âmbito governamental, notadamente (i) as atribuições e responsabilidades dos principais postos do governo, (ii) quem os ocupa, (iii) o relacionamento com os demais membros do Executivo, assim como com os partidos políticos, parlamentares e representantes dos estados e municípios, e (iv) as estratégias e recursos de poder empregados para negociar e produzir decisões.

Faltam, então, estudos que esclareçam a dinâmica e os procedimentos decisórios do poder Executivo, e forneçam respostas mais completas para a questão de "como se governa?". Tendo em vista esse quadro, propõe-se avançar no desenvolvimento de uma perspectiva que contribua para o entendimento de como os governos se organizam, funcionam e produzem decisões, sobretudo, para que se forme evidências que possibilitem compreender como os governos que se alternam no poder variam, ou mantêm proximidades entre si.

Argelina Figueiredo (2004) destaca que três aspectos devem ser considerados quanto à capacidade do governo em formular e implementar decisões: i) natureza da relação entre o Executivo e o Legislativo, ii) estrutura do próprio Executivo (relações entre a chefia do Executivo, ou do governo, e os ministros), iii) relações entre o Executivo político (a chefia do governo e seu gabinete) e a burocracia. Considerando esse esquema, pode-se notar que, do ponto de vista analítico, os processos de negociação e articulação que transcorrem na arena "pré-legislativa", conforme definiu Andrade (1998), são indispensáveis para entender os resultados das decisões de um governo.

Ainda segundo Figueiredo (2004), os estudos sobre o Executivo, no sistema de governo presidencialista, concentram-se em duas correntes, nas quais se organiza a ciência política norte-americana. A primeira aborda estudos sobre a Presidência e compreende um extenso volume de trabalhos com foco empírico nos Estados Unidos. Nestes estudos sobre a Presidência norte-americana, enfatizam-se seus aspectos individuais, explorando os diferentes estilos de liderança, e institucionais, destacando o aparato organizacional erguido em torno do presidente. A segunda corrente vincula-se à área de estudos sobre a América Latina, cujo foco são os aspectos institucionais do sistema de governo presidencial, sobretudo a relação entre Executivo e Legislativo, os poderes de agenda do presidente e os mecanismos de "checagem" dos parlamentares. Cumpre destacar que, de acordo com a autora, essas duas vertentes analíticas guardam 
considerável distância entre si, uma vez que privilegiam objetos distintos: a primeira tem como foco o poder Executivo, ou melhor, a Presidência, enquanto a segunda trata do presidencialismo, principalmente as questões referentes à separação de poder.

A autora esclarece que a ciência política norte-americana que é, então, tida como referência nas análises sobre o poder Executivo, em específico a presidência, ampara suas pesquisas em duas perspectivas analíticas, a behaviorista e a institucionalista. Um dos principais expoentes da perspectiva behaviorista é Richard Neustadt, autor da obra Presidential Power (NEUSTADT, 2008), que partindo de um enfoque sobre os aspectos subjetivos do chefe de governo, afirma que as forças que movem a política presidencial e determinam o seu sucesso são pessoais. Figueiredo afirma que para Neustadt a personalidade, o estilo e a habilidade do presidente, isto é, seus poderes informais, são condições fundamentais para o bom exercício do seu governo, por isso,

[...] uma liderança forte requer uma personalidade extraordinária, vontade política e habilidades especiais. Só um indivíduo dotado dessas qualidades pode explorar as oportunidades para maximizar sua influência no processo decisório e imprimir sua marca nas políticas públicas. A capacidade de realizar pessoalmente várias das funções para as quais o presidente dispõe de um significativo aparato organizacional é condição sine qua non para obter resultados em seu próprio favor. As funções de persuasão e barganha não podem ser transferidas. O presidente é também o único capaz de zelar pela sua reputação e prestígio. [...] o que significa que precisa ser altamente habilidoso na arte da política, ser altamente bem informado sobre as políticas públicas, as estratégias e as personalidades, ser altamente experiente nos caminhos do mundo político e entusiasticamente envolvido nas trocas miúdas do cotidiano da política (horse-trading) (FIGUEIREDO, 2004, p. 23).

Em seu trabalho, Neustadt procura caracterizar o poder de um presidente norte-americano moderno ${ }^{4}$. Para tanto, define poder como a influência pessoal sobre a ação governamental, diferenciando-o dos poderes formais atribuídos à presidência pela Constituição e outras legislações. Suas reflexões baseiam-se na suposição de que os poderes formais de um presidente "não representam nenhuma garantia de poder; o cargo não é garantia de liderança." Ou seja, os poderes formais inerentes ao cargo de

4 Diversos autores atribuem ao governo de Franklin Delano Roosevelt (1933-1945) o marco inicial para a modernização e institucionalização da presidência norte-americana, devido à criação em 1939 de uma "sem precedentes" estrutura central de assessoramento presidencial, o "Executive Office of the President" (EOP), e de um escritório composto por conselheiros e assessores da confiança do presidente ("White House Office" - WHO). Ver Burke (1992); Hart (1995); Rasgadale e Theis (1997). 
presidente não seriam suficientes para que suas ordens fossem realizadas automaticamente. Por isso, para Neustadt, "[...] apesar de sua posição, o chefe do Executivo não consegue ação sem argumentação. O poder presidencial é poder para persuadir" (NEUSTADT, 2008).

O famoso livro de Neustadt ("Presidential Power and the Modern Presidents") foi possivelmente a obra de maior influência no âmbito dos estudos presidenciais no século XX. Anthony King (1975, p. 174) observa no artigo Executives, em uma clara referência à popularidade acadêmica da obra de Neustadt, que

[...] ler os estudos mais gerais da presidência norte-americana é sentir que os autores não estão lendo livros diferentes, mas essencialmente o mesmo livro, cada vez mais. As mesmas fontes são citadas, os mesmos apontamentos são feitos, inclusive as mesmas citações aparecem.

Terry Moe (1985, 1990, 1993), importante estudioso da presidência norte-americana, cujos embasamentos teóricos apóiam-se na perspectiva de análise institucional e na teoria da escolha racional - conjugando-se em uma teoria positiva das instituições (positive theory of institutions) $-{ }^{5}$ questiona esse enfoque "pessoal" de Neustadt e argumenta que a Presidência se institucionalizou, isto é, cresceu e se desenvolveu, sendo, então, composta por centenas de indivíduos em cargos e funções que formam uma rede organizacional altamente diferenciada, estável e uniforme. Neste sentido, a base do poder presidencial não seria pessoal, como crê Neustadt, mas institucional, já que os presidentes exercem um conjunto de poderes formais, como, por exemplo, de administrar e controlar a burocracia pública.

Os poderes formais proporcionariam autoridade pública ao presidente, de modo que independe de suas habilidades "teria o direito de dizer aos demais [membros do governo e a burocracia] o que fazer, queiram eles ou não". Para Moe, uma consequência imediata do fato de que as instituições são os principais parâmetros da autoridade presidencial tem a ver com a forma como cada presidente "usa" e organiza sua estrutura de governo. Dessa forma, a partir do momento em que assumem seu mandato, os presidentes têm

5 Convém ressaltar que Peter Hall e Rosemary Taylor (2003) no artigo "Political Science and the three New Institutionalisms", reconhecendo que o novo institucionalismo não constitui uma corrente de pensamento unificada, classifica os estudos sobre as instituições políticas desenvolvidos com base na teoria da escolha racional como parte do institucionalismo da escolha racional. Em paralelo, existiriam ainda o institucionalismo histórico e o sociológico. Os trabalhos de Moe, contudo, não seguem essa classificação. A perspectiva institucional sistematicamente tratada em seus textos, embora tenha sido definida por Hall e Taylor como parte do institucionalismo da escolha racional, é concebida pelo autor como a teoria positiva das instituições (positive theory of institutions, ou PTI). 
o poder de "desenhar novas estruturas e assim perseguir seus interesses". Nas palavras de Moe é possível verificar essa dinâmica,

Muitas instituições políticas são instâncias do exercício de autoridade pública. Elas surgem de disputas em torno de escolhas estruturais em que os 'vencedores' utilizam o usufruto temporário da autoridade pública para desenhar novas estruturas e impô-las ao ambiente político como um todo. Essas estruturas são simplesmente veículos pelos quais perseguem seus interesses, frequentemente, a expensas dos 'perdedores'. Muitas estruturas podem administrar programas que suprem os 'vencedores' com algum tipo de benefícios. Outras podem extrair recursos ou ajustes custosos de comportamento por parte dos'perdedores.' Além disso, outras estrutuas podem impor novos constrangimentos na forma como o jogo político se organizará no futuro; constrangimentos que dão aos 'vencedores' de hoje vantagens sobre seus oponentes nas disputas futuras em torno da autoridade pública (MOE, 1990, p. 222).

Considerando as instituições políticas na concepção de Douglass North (1990, p. 97), segundo a qual "[...] as instituições são regras e processos que orientam as relações humanas, estabelecendo estruturas para a interação dos agentes, e influenciando o desempenho da prática política", entende-se que as instituições formais da Presidência, tais como leis, normas e dispositivos, que dispõem sobre as competências, responsabilidades e procedimentos de deliberação e decisão do presidente, constituem-se os instrumentos que facultam autoridade pública ao chefe do Executivo. Neste sentido, quanto aos processos de governo, a Presidência é um lócus central para se entender como surgem e se configuram as decisões governamentais.

Ainda segundo Terry Moe (1993, p. 342), a delegação de funções é a característica fundamental da moderna presidência. Para governar, o presidente se apoiaria na estrutura institucional da presidência que se "[...] apropriadamente projetada, capacitaria um grupo de auxiliares para tomar ações efetivas seguindo os interesses do presidente". As responsabilidades do cargo simplesmente ultrapassariam sua capacidade para executá-las sozinho.

Nos Estados Unidos do século XX, no decorrer de seguidas administrações, essa estrutura institucional cresceu progressivamente. Assim, grande parte das decisões governamentais passou a ser tomada por auxiliares e especialistas distribuídos em diferentes escritórios do "Executive Office of the President". Rotineiramente, decisões e ações da presidência passaram a se realizar por meio de canais e procedimentos 
institucionalizados sobre os quais os presidentes não teriam um controle específico. A característica principal da presidência moderna seria, então, o seu funcionamento em bases formais e impessoais. Por essa razão, a concepção teórica que enfatiza o aspecto pessoal da presidência estaria ultrapassada. Em sua substituição, Moe sugere a "presidência institucional" como a abordagem capaz de descrever e explicar mais adequadamente o funcionamento da presidência.

Do processo de institucionalização da presidência resulta a sua configuração como uma instituição na qual os presidentes são, consequentemente, atores institucionais que obedecem a um conjunto de leis e expectativas bem especificadas, e cujos cursos de ação e incentivos se estruturam pelas regras e procedimentos que regulam o seu cargo. Deste modo, grande parte do comportamento presidencial é impessoal e todos os presidentes, sejam quais forem suas personalidades, estilos e background, tenderão a se comportar similarmente em diversos aspectos (MOE, 1993, p. 337). É neste sentido que Moe concebe a presidência institucional moderna, isto é, como uma instituição composta por normas e rotinas que fixam condutas e comportamentos e, além disso, incentivos e constrangimentos às ações do presidente, seja ele quem for.

No artigo "Politicized Presidency", Moe (1985) argumenta que o desenvolvimento institucional observado na presidência norte-americana ao longo do século XX, reflete o conjunto de responsabilidades e expectativas públicas crescentemente atribuídas aos presidentes - e também reivindicadas por eles - neste período. Em função disso, "[...] os presidentes modernos são induzidos a buscar [centralizar] controle sobre as estruturas e processos [de tomada de decisão] do governo"(MOE, 1985, p. 238). Essa propensão deve ser entendida como resultado dos incentivos que a própria moderna presidência induz ao chefe do Executivo, já que ao longo do tempo e sob a responsabilidade de cumprir um conjunto cada vez maior de atribuições e expectativas, sua tendência é procurar expandir sua capacidade de comando e controle sobre o processo decisório de políticas públicas governamentais (especificamente, as etapas relativas à elaboração/projeção das políticas, sua proposição, submissão ao Legislativo, execução/administração e possíveis modificações futuras).

No processo decisório, adverte Moe, o presidente está suscetível a diversos constrangimentos de natureza interna, como as pressões de tempo e de limites impostos por conhecimento inadequado sobre, por exemplo, uma política emergencial ou prioritária que deve ser posta em prática pelo governo, e externa, como as que 
provêm das (possíveis) resistências da burocracia e do Congresso em acatar seus projetos e resoluções, ou seja, em efetivar políticas públicas em acordo com seu conjunto de preferências e interesses. Diante disto, os presidentes tendem a reagir a este contexto adotando estratégias semelhantes para tentar assegurar altos níveis de autoridade e controle sobre as estruturas e os processos de decisão governamental. A despeito das características individuais e ideológicas de cada presidente, seus incentivos para agir são estruturados de forma similar com vistas a controlar as decisões que importam ao governo.

Em termos gerais, Moe observa que as estratégias empregadas pelo presidente para comandar e controlar o processo de produção de políticas governamental são moldadas "[...] pelos recursos de que dispõe e pela flexibilidade com que esses recursos podem ser utilizados"(MOE, 1985, p. 240). Concretamente, o conjunto de normas, regras e estruturas que constitui a Presidência e configura o ambiente institucional no qual os presidentes estão inseridos é que define os recursos e as oportunidades para a ação presidencial. As estratégias e cursos de ação dos presidentes são, então, realizados por meio de "[...] estruturas e recursos próximos a eles e pouco controladas pelos outros membros do governo" (MOE, 1985, p. 243). Neste sentido, os presidentes recorrentemente se apoiam nas organizações que estão sob o seu comando direto, como a estrutura da Casa Branca (o "Executive Office of the President" e o "White House Office") composta por órgãos que Ihes são diretamente subordinados e conselheiros e assessores de sua confiança.

Este contexto institucional proporciona recursos e oportunidades que induzem os presidentes à escolha de estratégias semelhantes, como as de "centralizar" e "politizar ou presidencializar" a administração governamental. Ou seja, por meio da estrutura da Casa Branca, o presidente centralizaria a gestão de importantes questões do governo, e com base em sua prerrogativa de realizar indicações políticas para ocupar cargos de livre nomeação (political appointees) na burocracia federal providenciaria o recrutamento de pessoas leais, que representariam os seus interesses em organizações com agendas e lealdades políticas divergentes, e ainda expandiria o número desses cargos, como explicitado na passagem abaixo.

Em resumo, a moldura institucional da moderna presidência induz cada presidente a "centralizar" e "presidencializar" - centralizar a presidência institucional na Casa Branca (alocando problemas e questões que estavam sob controle de outra unidade para as mãos de um staff amplo e mais especializado da Casa Branca), e presidencializar, que é embutir 
seus interesses em instituições com outras agendas e relações de lealdade por meio do crescimento do número e posição de nomeações políticas e pela nomeação de indivíduos com base na lealdade pessoal, ideologia ou apoio programático, mediante qualquer outro critério (MOE, 1985, p. 246, tradução nossa).

Vale frisar que Moe elenca três razões que atestam a importância de se tomar os presidentes, e consequentemente a Presidência, como foco de análise numa investigação teórica sobre processos de governo. Com isso, o autor visa apontar para a relevância de uma perspectiva teórica sobre a presidência que possa se tornar referência aos estudos desse tema, inclusive como parâmetro para análises comparativas. A proposta de Moe se adequa ao objetivo do presente trabalho e pode ser utilizada como um referencial para a análise da presidência brasileira, especialmente numa perspectiva que destaque como os presidentes fazem uso de sua estrutura de poder para a consecução de seus projetos e decisões.

O autor justifica, portanto, seu argumento com base em três razões, são elas: i) os presidentes são atores poderosos na escolha de sua estrutura de governo. Seus mecanismos de ação vão além de seu recurso formal de vetar legislação, uma vez que detêm um conjunto de poderes formalizados pelos quais podem agir unilateralmente, criando, por exemplo, uma nova estrutura administrativa que atenda a seus interesses na implementação de seus projetos de governo, sem precisar se submeter ao processo legislativo; ii) os presidentes são vistos pelo público como responsáveis por praticamente todos os aspectos do desempenho do governo, que colocam em jogo sua reputação, popularidade e, em alguns casos, a possibilidade de reeleição. Sendo assim, os presidentes preocupam-se fundamentalmente com problemas de governança, visando construir e organizar uma capacidade institucional para o governo efetivo, possuindo motivação para construir "um sistema burocrático centralmente unificado e coordenado; iii) os presidentes dispõem de relativa autonomia, que decorrem, sobretudo, de sua base eleitoral ampla, heterogênea e competitiva, e também do fato de que sua equipe age "como um time", sendo reduzidos os problemas de ação coletiva. Neste caso, os chefes de governo possuem mais autonomia para definir sua própria agenda pública, além do que dispõem de condições que possibilitam o estabelecimento de estruturas de governo centralizadas de controle sobre os órgãos da Presidência e da burocracia pública (MOE, 1990, p. 236-238). 
À primeira vista, no que concerne às perspectivas de análise para o caso do Brasil, os fatores elencados por Moe suscitam atenção sobre (i) os dispositivos que regulam a organização e estrutura do poder Executivo, isto é, os processos pelos quais o presidente pode estabelecer mudanças no arranjo organizacional da Presidência, considerando, para tanto, se o chefe de governo possui a prerrogativa de estabelecer novas instruções normativas e mudanças unilateralmente, ou se há a necessidade de submissão ao

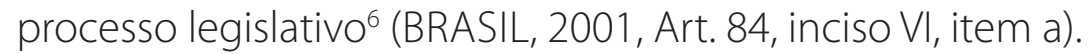

A análise de Moe também sugere (ii) um enfoque sobre a composição do poder Executivo, tendo em vista a suposição de que o governo enfrente menos problemas de ação coletiva, em comparação ao Legislativo, devido à ação "como um time" dos atores governamentais (por exemplo, os ministros e secretários). Certamente, no caso brasileiro, essa suposição é controversa, sobretudo se considerarmos a dinâmica de governo engendrada pelo "presidencialismo de coalizão" vigente na Nova República, que se baseia na formação de uma coalizão parlamentar governista em contrapartida ao preenchimento de postos no gabinete presidencial pelos partidos aliados. Vicente Palermo (2000), considerando os efeitos que essa dinâmica proporciona ao governo, entende que ao mesmo tempo em que proporciona certa previsibilidade na sua relação com a arena legislativa, introjeta na presidência, mediante a coalizão de partidos aliados, atores políticos

[...] representantes de partidos/regiões, que podem expressar interesses e orientações relativamente diferentes das do presidente, e que dispõe de certa margem de autonomia no processo de formulação de políticas no governo (PALERMO, 2000, p. 545).

Em função desses aspectos, que derivam do governo de coalizão, não se supõe que a presidência brasileira esteja imune a conflitos internos e a problemas de ação coletiva. Neste sentido, cabe atentar para as "relações de confiança" que fazem parte do governo, especialmente na cúpula presidencial, e que podem constituir instrumentos centrais pelos quais o presidente construa suas estratégias de governo. Considera-se que a Casa Civil e os demais órgãos de assessoramento direto da Presidência, devido à

6 Vale lembrar que de acordo com a emenda constitucional 32, de 2001, o presidente da República só poderá dispor por decreto (isto é, unilateralmente, sem a aquiescência do Congresso Nacional) sobre a organização e o funcionamento da administração pública federal, caso suas medidas não impliquem aumento de gastos ou a criação e extinção de órgãos públicos. Nas situações que prevejam a ocorrência de um desses dois casos, o presidente deverá submeter sua proposta, em forma de projeto de lei, ao trâmite legislativo (BRASIL, 2001). 
vinculação direta com o presidente, se constituam o lócus dessas "relações de confiança", para onde o chefe do Executivo escolheria estrategicamente seus respectivos titulares em função do "uso" que pretendesse fazer desses órgãos.

\section{Presidencialismo no Brasil: o que se sabe e o que é preciso ainda saber}

Pode-se afirmar que a produção dos países latino-americanos no âmbito dos estudos sobre o presidencialismo foi, desde a década de 1980, quando uma onda de redemocratização marcou o desfecho de regimes autoritários em vários países da região, influenciada por trabalhos acadêmicos que tratavam da transição política em andamento. Esses trabalhos levantavam questionamentos sobre a capacidade do sistema presidencialista em sustentar um regime democrático estável. Juan Linz e Scott Mainwaring foram alguns dos críticos que questionavam a manutenção do sistema de governo presidencialista nos países latino-americanos que então se redemocratizavam.

Ao longo das últimas três décadas do século XX, Juan Linz (1990) elaborou diversas publicações explorando os "riscos do presidencialismo." Segundo o autor, historicamente os países com sistema de governo parlamentarista demonstraram ter um regime democrático mais estável do que os países presidencialistas. O presidencialismo seria propenso a situações de instabilidade. Essa tendência, na visão de Linz, se explicaria por algumas condições institucionais do sistema presidencialista, como, por exemplo, i) a sua dupla legitimidade, depositada no Executivo e no Legislativo, que poderia potencializar conflitos e polarizações entre os dois poderes, caso não fossem compostos pela mesma maioria partidária, dado que cada um dos dois seria um legítimo representante da vontade popular; ii) a regra da maioria (eleição majoritária) que outorga ao vencedor da eleição presidencial o direito de compor o governo autonomamente - sem a aquiescência ou participação do Legislativo, ou a necessidade de compartilhar poder e formar coalizões - que poderia resultar num "jogo de soma zero" entre o presidente e o Parlamento; iii) a rigidez do mandato presidencial que não deixaria margens para flexibilidades e ajustes no manejo de crises que afetassem o chefe do Executivo que, exceto em situações de renúncia ou impeachment, cumpriria o mandato fixado constitucionalmente mesmo 
enfrentando, por exemplo, forte oposição parlamentar, ou ainda desconfiança ou rejeição da opinião pública e da própria classe política.

Seguindo as críticas de Linz, Scott Mainwaring também procurou em diversos trabalhos explicar as dificuldades de se erigir uma democracia estável em países com sistema presidencialista, sobretudo, quando houvesse a combinação com um sistema multipartidário fragmentado. O autor, atento à redemocratização do Brasil e às conjunturas dos governos José Sarney (1985-1990) e Fernando Collor (1990-1992), consideraria fundamental que as análises sobre o funcionamento de sistemas presidencialistas levassem em conta as combinações institucionais, uma vez que no presidencialismo a"[...] natureza do sistema eleitoral e partidário explicam as dificuldades que o presidente pode enfrentar para implementar suas agendas" (MAINWARING, 1993). Nesta visão, a combinação do presidencialismo e multipartidarismo com partidos poucos coesos tornaria difícil ao presidente obter maioria no Legislativo e, dada a ausência de mecanismos para lidar com situações de impasse como essa, poderia resultar num quadro de paralisia decisória que comprometeria a estabilidade do regime político.

A literatura brasileira sobre presidencialismo, fortemente influenciada pelo seminal artigo de Sergio Abranches (1988), em sua maior parte se desenvolveu como uma resposta a esses questionamentos que punham em dúvida a estabilidade do sistema presidencial em contextos políticos semelhantes ao brasileiro (FIGUEIREDO; LIMONGI, 1994, 2001; SANTOS, 1997, 1999; AMORIM NETO, 2000; NICOLAU, 2000; AMORIM NETO; SANTOS, 2001) e também fortemente influenciada pelo seminal artigo de Sergio Abranches (1988) ${ }^{7}$. Assim, procurando investigar empiricamente como em cada governo se organizavam e funcionavam as relações entre o Executivo e Legislativo, a partir da década de 1990 foram desenvolvidos diversos trabalhos baseados em levantamentos empíricos que mostravam a dinâmica de relacionamento entre os poderes.

Esses estudos representaram, de fato, um ponto de inflexão nos debates e interpretações sobre o sistema político no Brasil, mostrando, primeiramente, que não seria correto afirmar aprioristicamente o caráter instável do sistema presidencial, quando

7 O termo "presidencialismo de coalizão" foi cunhado por Sérgio Abranches (1988) para definir uma dinâmica de governo que poderia emergir em um regime presidencialista tal como o estabelecido no Brasil a partir da Constituição de 1988. Numa situação de multipartidarismo em que o partido do chefe do Executivo não disponha da maioria das cadeiras no Legislativo, fazer-se-ia necessário a construção de uma coalizão partidária de apoio ao presidente no Parlamento para garantir a governabilidade, conferindo, como contrapartida, aos partidos da coalizão espaço na composição das pastas ministeriais no Executivo. Desse modo, a formação e duração de coalizões legislativas em favor do governo seriam função de acordos estabelecidos entre o chefe do Executivo e os partidos com assento no Legislativo, acordos que envolvem a distribuição de postos ministeriais a políticos ou pessoas indicadas pelos partidos, e apoio destes à agenda proposta pelo governo no Congresso. 
na realidade observar-se-ia a existência de diferentes modalidades de presidencialismo, que se formariam a partir de variações institucionais. Assim, adotando uma perspectiva de análise institucionalista, enfocando variáveis até então ignoradas nas interpretações sobre o presidencialismo na América Latina, esses estudos revelaram que "os efeitos da organização interna do Congresso Nacional e a extensão dos poderes de agenda do presidente ${ }^{8}$ no funcionamento do sistema político brasileiro" proporcionam uma dinâmica de relacionamento pouco propensa à paralisia decisória entre o governo e o Legislativo.

Como efeito, nas últimas décadas, a literatura brasileira sobre presidencialismo9", tomando como objeto de estudo sistemático as relações entre o Executivo e Legislativo, suscitou importantes avanços no entendimento sobre a funcionalidade do sistema de separação de poderes no Brasil, enfatizando suas bases institucionais ${ }^{10}$. A maioria dos trabalhos se deteve (i) na análise do funcionamento do Congresso Nacional, precisamente na tramitação das medidas legislativas - sobretudo, medidas provisórias (MPs) e projetos de lei (PLs) - encaminhadas pelo Executivo e (ii) no comportamento dos partidos e das coalizões político-partidárias, em especial, no grau de apoio que oferecem às matérias provenientes do governo.

Com o intuito de avaliar os níveis de governabilidade entre os poderes, isto é, a capacidade em aprovar leis (ou melhor, em produzir decisões), grande parte da literatura convergiu no entendimento de que o presidencialismo no Brasil opera de forma relativamente estável. Em termos empíricos, os governos de Fernando Henrique Cardoso (FHC) (1995-2002) e de Luiz Inácio Lula da Silva (2003-2010) demonstraram que a montagem de uma base partidária, adicionalmente à extensão dos poderes legislativos do presidente e aos efeitos da organização interna do Congresso Nacional, produziu na maior parte do tempo - ou de um

8 Sucintamente, os poderes de agenda do presidente brasileiro, conforme as disposições definidas pela Constituição de 1988, consistem na (i) iniciativa exclusiva de leis, (ii) solicitação de urgência no trâmite de legislação no Congresso Nacional com a edição de medidas provisórias - MP, (iii) poder de veto, e (iv) edição de decretos.

9 Alguns dos trabalhos que produziram importantes contribuições à compreensão do funcionamento do presidencialismo após a redemocratização, em 1985 e a promulgação da Constituição Federal de 1988 (CF/1988), foram: Abranches (1988), Amorim Neto (1994, 2000), Amorim Neto e Santos (2001), Figueiredo e Limongi (2001, 2007), Meneguello (1998), Nicolau (2000), Santos (1997, 2002), entre outros.

10 Os instrumentos institucionais que caracterizam o presidencialismo de coalizão brasileiro são: os poderes legislativos do presidente, que consistem na prerrogativa exclusiva de iniciar legislação (em matérias orçamentárias, tributárias e relativas à organização administrativa), de forçar unilateralmente a apreciação das matérias que introduz no Legislativo dentro de determinados prazos (pedido de urgência) e de editar medidas provisórias em caso de relevância e urgência; a formação de gabinetes de coalizão, por meio dos quais os diferentes partidos integram o Executivo, proporcionando ao governo o respaldo parlamentar necessário; o padrão organizacional centralizado do processo decisório na Câmara dos Deputados e no Senado, estabelecido pelos respectivos regimentos internos, que conferem amplos poderes aos líderes partidários para agir em nome dos interesses de seus partidos e, por consequência, controlar o fluxo dos trabalhos parlamentares; a disciplina partidária no Congresso Nacional. 
mandato - apoio ao Executivo no Congresso (FIGUEIREDO, 2007). Como resultado, houve no período de exercício de ambos os governos, um quadro de hipertrofia do Executivo, caracterizado pela predominância deste poder no processo legislativo (MOISÉS, 2011).

Tornou-se, então, recorrente na literatura sobre presidencialismo no Brasil o argumento de que o chefe do Executivo seria dotado de extensos poderes legislativos que Ihe confeririam uma posição de preponderância, sobretudo na relação com o Congresso. Comumente, preponderância do presidente seria avaliada por meio do êxito em influenciar o processo legislativo em torno das preferências governamentais, ou seja, na capacidade de influir nos resultados do processo legislativo de modo que sejam favoráveis às proposições e interesses do Executivo. Nesta avaliação, o que explicaria a posição predominante do presidente na relação com o Congresso seriam suas prerrogativas de poder legislativo e de barganha que incentivariam a cooperação da coalizão e de suas respectivas lideranças às preferências do governo.

Este trabalho, todavia, considera que grande parte da literatura que destaca a dominância do Executivo no sistema político nacional baseia-se em um entendimento unilateral e, portanto, parcial a respeito da cooperação de uma maioria congressual com a agenda presidencial. A compreensão de que as prerrogativas presidenciais incentivam à cooperação do Congresso tende a enfatizar o caráter coercitivo dos incentivos e, logo, da cooperação. Neste raciocínio, o presidente, devido às suas prerrogativas, garantiria unilateralmente a colaboração da coalizão. Contudo, conforme afirma Palermo (2000), as fórmulas de cooperação entre presidente e Congresso podem ser de dois tipos: a de sujeição e/ou a de negociação, ou busca de consenso. Não éforçoso dizer que nos estudos sobre presidencialismo no Brasil a dimensão da negociação tem sido negligenciada.

Tem-se aqui, então, o objetivo de problematizar o entendimento sobre a preponderância institucional do presidente na relação com a coalizão e o Congresso. Esta problematização não se fundamenta, todavia, em uma presunção de que o presidente não exerça uma posição dominante. O que se pretende explicitar são algumas das condições que sustentam esta posição. Supõe-se, então, que a cooperação verificada entre os poderes no Brasil é possivelmente negociada em momentos específicos. Este trabalho pretende argumentar que, a despeito de suas prerrogativas, o presidente pode estar suscetível a pressões que derivam dos compromissos com sua base partidária de apoio parlamentar, que podem inclusive atingir a sua própria esfera de poder, a presidência. 
Há evidências empíricas coletadas em trabalhos anteriores (LAMEIRÃO, 2015a, b) sugerindo que em períodos específicos nas gestões de FHC e Lula houve, por parte do Executivo, esforços para obter respaldo da base partidária que não se limitaram a concessão de cargos ministeriais; em algum nível, foi transferido a autoridades provenientes do Legislativo o comando da coordenação política e a administração dos recursos de negociação com os partidos aliados.

É possível aventar que a coincidência dessas concessões por parte do presidente sugere, no mínimo, capacidade de barganha dos partidos da coalizão. Seguindo este raciocínio, os partidos teriam o potencial de criar obstáculos às ações do governo no processo legislativo. Caberia ao governo antecipar-se ou contornar as potenciais ameaças com o objetivo de angariar a cooperação de sua base. Pode-se argumentar que a concessão de poderes aos partidos da base seria uma das condições cumpridas pelo presidente para potencializar sua posição institucional dominante.

Supondo que a cooperação legislativa entre coalizão e governo ocorra por meio de negociações, este trabalho propõe uma investigação sobre as estruturas da presidência projetadas para promover a coordenação política governamental. Observar-se-á, sobretudo, o tipo de controle que os presidentes mantêm sobre o desenho institucional destas estruturas. Isto proporcionará um parâmetro para avaliar o escopo do seu controle sobre a relação com a coalizão e o Congresso e dimensionar, em alguma medida, sua preponderância no sistema político. Pode-se considerar que quanto mais centralizado for o arranjo de coordenação política da presidência, maior controle o presidente exercerá sobre a relação do seu governo com o Congresso e a coalizão. Por outro lado, quanto mais descentralizado for este arranjo, menor seria o controle presidencial.

\section{A estrutura de coordenação política da Presidência ${ }^{11}$ : histórico e mudanças institucionais}

Com a redemocratização do país, em 1985, definiu-se como uma das principais incumbências da Casa Civil a coordenação política do governo. Nesta função, precisamente, caberia à Casa Civil assistir o presidente nas relações com parlamentares, partidos políticos, autoridades governamentais e o Congresso Nacional. Para tanto, um

11 Para uma detalhada descrição sobre essa estrutura, ver Lameirão (2015a, b). 
órgão específico de sua estrutura - a Subchefia de Assuntos Parlamentares - estaria diretamente dedicado a esta função.

As atribuições encarregadas à Subchefia de Assuntos Parlamentares foram fixadas já no primeiro regimento da Casa Civil - Decreto n 92.400/1986 - editado no período democrático, especificamente em 1986, no segundo ano do governo de José Sarney. Seriam elas: i) preparar os expedientes necessários ao envio de mensagens do presidente ao Poder Legislativo; ii) acompanhar a tramitação de proposições nas Casas do Congresso Nacional, organizando sinopse legislativa; iii) providenciar respostas aos pedidos de audiência ou de informações formulados por membros do Congresso Nacional, colhendo dos ministérios e demais órgãos da administração federal os elementos necessários; iv) proceder estudos e formular sugestões sobre assuntos legislativos, especialmente projetos de lei de iniciativa do Poder Executivo; v) coordenar os trabalhos das assessorias parlamentares ou legislativas dos ministérios e demais órgãos da administração federal; vi) manter contatos regulares com as mesas e as lideranças das Casas do Congresso Nacional; e vii) examinar os projetos de lei submetidos à sanção do presidente da República, consultando os ministérios e órgãos interessados para instruir a decisão presidencial (BRASIL, 1986, Art. 12, incisos I ao VII).

A organização de competências e de uma estrutura específica de natureza político-parlamentar na Presidência, especificamente na Casa Civil, para promover a coordenação do governo com o Congresso Nacional é coerente com o novo momento político do Brasil, a partir de 1985, com a redemocratização e a vigência de um regime de separação de poderes, adensado por um sistema multipartidário competitivo.

Um dado interessante que revela a funcionalidade desse tipo de estrutura incumbida da coordenação política diz respeito à experiência do governo de Fernando Collor de Mello (1990-1992), que iniciou seu mandato extinguindo a Casa Civil e, por conseguinte, sua estrutura interna, e instituindo em seu lugar uma Secretaria-Geral, cujas funções não previam a de assistir o presidente no desempenho da coordenação política do governo.

Ao longo mandato, no entanto, principalmente no período em que houve um quadro de grande dificuldade para governar, Collor reintroduziu no âmbito da Presidência uma estrutura de coordenação política nos moldes da que existia no mandato de Sarney. Assim, foi em meio às crises de natureza econômica - concernentes ao fracasso dos planos de estabilização monetária - e política - relativa às crescentes denúncias de 
corrupção envolvendo membros do alto escalão governamental -, entre 1991 e 1992, que foi instituída a Secretaria de Governo ${ }^{12}$. O comando do órgão foi entregue a Jorge Bornhausen, então presidente nacional do Partido da Frente Liberal (PFL) ${ }^{13}$, e um dos principais interlocutores do então presidente Collor para a promoção de uma reforma ministerial, em 1992, que procuraria aproximar o governo dos partidos, como forma de obter respaldo político no Congresso, em troca de pastas ministeriais.

A Secretaria de Governo foi vinculada administrativamente à Secretaria-Geral (SG) e encarregada da finalidade específica de assistir direta e imediatamente o presidente no desempenho de suas atribuições nos assuntos referentes ao acompanhamento de ações e políticas governamentais e no relacionamento com os estados e municípios. A medida foi entendida como uma estratégia para fortalecer a articulação política do governo, reabilitando uma das funções pertinentes à antiga Casa Civil, ou seja, a coordenação e articulação política com o Congresso e os partidos políticos (ALUM JUNIOR; CASARÕES, 2011, p.182). A criação da Secretaria de Governo reestabeleceria canais de interlocução entre a Presidência, as instituições e autoridades políticas que formalmente foram suspensos com a extinção da Casa Civil, em 1990.

Após a experiência do governo Collor, todos os presidentes que se alternaram no poder mantiveram na estrutura da Presidência um órgão formalmente incumbido de tratar dos assuntos parlamentares. Contudo, este órgão, responsável por mediar a relação do governo com o Congresso, não se manteve sob o organograma da Casa Civil. Ao longo do tempo, houve variações em relação ao seu posicionamento no interior da Presidência, ora como parte da estrutura hierárquica da Casa Civil, ora como um órgão, em tese, independente.

Assim, especificamente nos governos de FHC e Lula, não obstante os esforços iniciais de concentrar na Casa Civil, bem como sob a responsabilidade de um restrito número de assessores presidenciais a condução da relação entre o governo e o Congresso (parlamentares e lideranças partidária), houve mudanças institucionais que redefiniram o organograma e as atribuições da Presidência no que concerne à relação com o Legislativo.

12 Pela Lei n 8.410, de 27 de março de 1992.

13 Na reforma ministerial promovida por Collor em 1992, das nove nomeações feitas, três eram indicações do Partido da Frente Liberal (PFL), respectivamente, para as pastas da Educação e Cultura, Previdência Social e Ação Social. Além delas, houve a nomeação de Bornhausen para o comando da recém-criada Secretaria de Governo. 
Nos dois governos (FHC e Lula), essas mudanças se originaram a partir do desmembramento da estrutura da Casa Civil, que teve parte de sua organização interna transferida para uma nova secretaria presidencial. Basicamente, em ambos os governos, criou-se uma nova secretaria no âmbito da Presidência para tratar da coordenação política governamental junto ao Congresso Nacional, a partidos políticos e aos estados e municípios. Estas transformações explicitam a forma como as estruturas da Presidência são manejadas para cumprir e atender aos interesses presidenciais, sob diferentes contextos e conjunturas políticas.

Pela regularidade com que ocorreu o desmembramento da estrutura da Casa Civil nos dois governos, de FHC e Lula, e dada as funções de natureza política da nova secretaria, é possível que esta mudança institucional visasse atender objetivos similares, como os de reforçar a interlocução do governo com o Congresso, precisamente com a coalizão partidária para obter apoio parlamentar.

Entretanto, esse movimento, aparentemente similar, de desconcentração de atribuições e órgãos da Casa Civil em curso nos governos dos dois presidentes apresentou contornos diferenciados. Embora as novas secretarias tenham sido incumbidas em grande parte de funções similares, os presidentes FHC e Lula delegaram-Ihes algumas atribuições específicas: à Secretaria-Geral, estabelecida em 1999, coube controlar as indicações para o provimento dos cargos da burocracia federal, enquanto a Secretaria de Coordenação Política e Assuntos Institucionais, criada em 2004, foi encarregada de tratar junto aos órgãos governamentais da liberação das emendas orçamentárias dos parlamentares ${ }^{14}$.

\section{Níveis de (des)centralização dos arranjos de coordenação política nos governos FHC e Lula}

O Anexo A deste artigo expõe algumas variáveis que permitem identificar o nível de centralização/descentralização característico às mudanças institucionais que envolveram a estrutura de coordenação política presidencial. Especificamente, são quatro as variáveis que informam sobre o tipo de arranjo desta estrutura: i) posição hierárquica na Presidência - vinculada à Casa Civil ou independente; ii) partido do titular do órgão - filiado ao partido do presidente ou da base aliada; iii) cargo

14 Ver, respectivamente, Decretos n. 4.451"(Art. 30, inciso IV) de 2002 (BRASIL, 2002) e n. 6.207 (Art. 60, inciso VIII) de 2007 (BRASIL, 2007). 
imediatamente anterior do titular - da assessoria do presidente ou parlamentar, eletivo; e iv) atribuição atinente aos cargos de livre provimento da administração federal e/ou a emendas orçamentárias.

Considerando a transferência das competências relativas à coordenação política da Casa Civil para um órgão à parte da Presidência, recorrente nos dois governos analisados, procura-se a partir das variáveis elencadas definir, em algum nível, se essas mudanças teriam o potencial de diminuir o controle do presidente sobre a coordenação política de seu governo. Supõe-se que um arranjo descentralizado teria este potencial.

Entende-se como centralizado um arranjo em que haveria concentração na Casa Civil - entendida como o principal órgão de assessoramento do presidente da competência de tratar da coordenação política governamental. Sob o escopo da Casa Civil, seria presumível que esta função fosse exercida por um assessor de confiança do presidente e, assim, segundo os seus interesses. Por seu turno, um arranjo descentralizado caracterizar-se-ia por uma estrutura independente da Casa Civil, com competência formal de controlar os recursos de interesse dos parlamentares e partidos, sobretudo da coalizão, no Legislativo, quais sejam, cargos de confiança e emendas orçamentárias. Além destes aspectos institucionais, o comando desta estrutura estaria a cargo de um político egresso do Legislativo e filiado a algum partido da coalizão.

Para tornar mais preciso os dados expostos no Anexo A, foi atribuída uma pontuação às quatro variáveis que informam a respeito do nível de centralização/ descentralização dos arranjos ${ }^{15}$. Em termos gerais, quanto mais próximo a quatro pontos, a estrutura de coordenação política apresentaria um formato descentralizado; em contraposição, nos casos próximos a zero, o formato seria centralizado. O somatório verificado em cada período de um governo está disposto no Gráfico 1.

Inicialmente, chama atenção a vigência dos níveis mais baixos de descentralização da estrutura de coordenação política exatamente nos anos inaugurais dos governos

15 Para a variável posição hierárquica na $P R$ - V1, no caso em que a estrutura for vinculada à Casa Civil não se atribui ponto; se for independente, soma-se um (1) ponto. Na variável partido do titular do órgão - V2, se for do partido do presidente (PSDB ou PT), não há pontuação, se o partido for da base aliada, soma um (1) ponto. Em relação ao cargo anterior do titular - V3, caso seja de assessoria ao presidente (inclusive de ministro), não se atribui ponto; na situação de ser um egresso do Legislativo, soma-se um (1) ponto. Por fim, a variável funções relativas a cargos e emendas orçamentárias - V4, quando prevista agrega um (1) ponto. Para a distribuição da pontuação, ver Anexo B. 


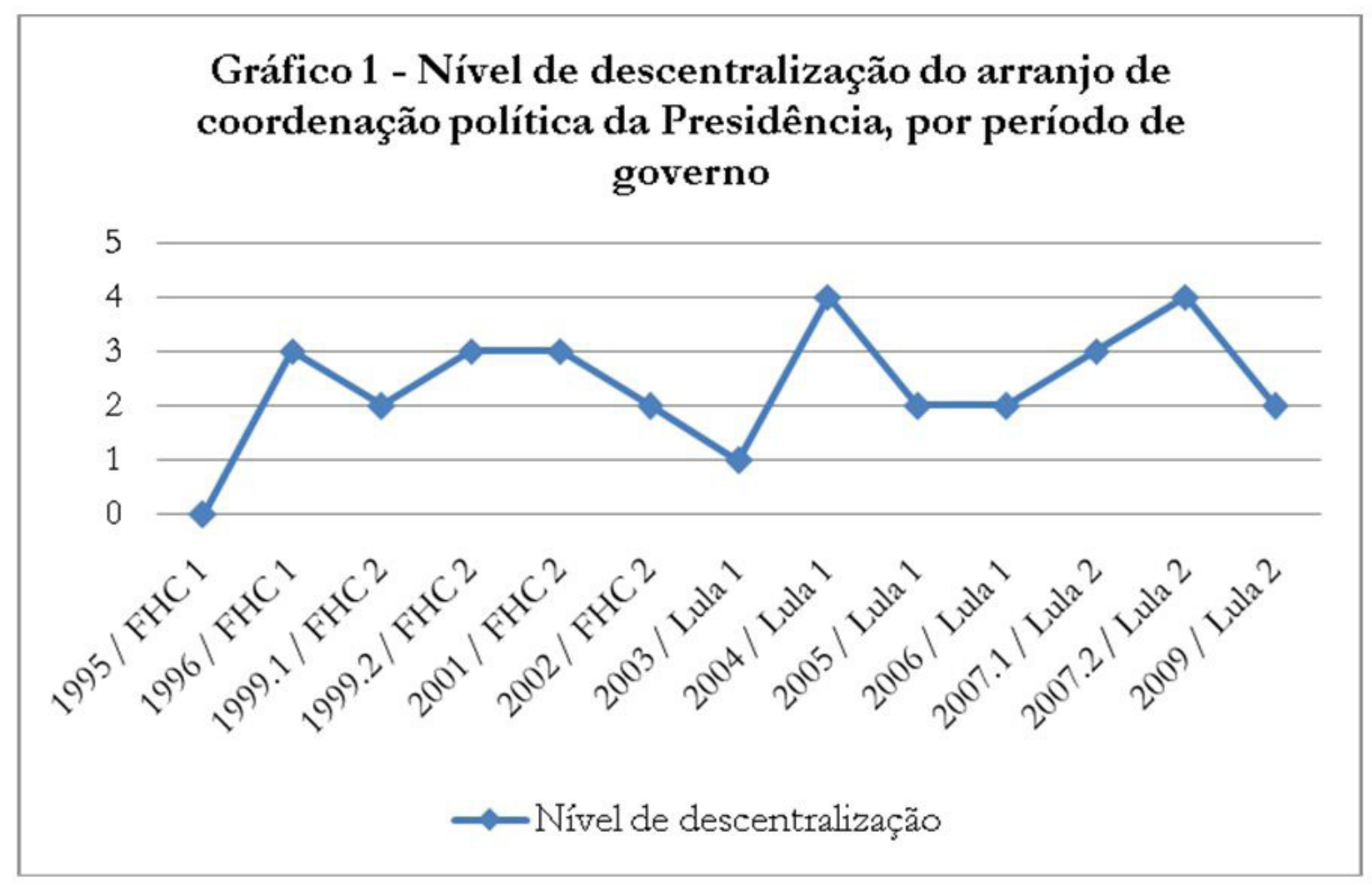

Gráfico 1. Nível de descentralização. Fonte: Elaboração da autora.

FHC e Lula (1995 e 2003). Também de forma congruente, observa-se que em ambos os governos, no segundo ano dos respectivos mandatos (1996 e 2004) há um incremento expressivo no nível de descentralização da estrutura de coordenação política presidencial. Nota-se, assim, que os dois presidentes privilegiaram estratégias de concentração da coordenação política ao iniciar seus mandatos, mas, em um segundo momento, empreenderam movimentos de descentralização em relação às estruturas e competências de coordenação política no interior da Presidência.

No governo FHC, o nível máximo de descentralização verificado totalizou três (3) pontos e pode-se dizer que vigorou durante boa parte de seus dois mandatos: a partir de 1996, no primeiro, e entre a segunda metade de 1999 a 2001, durante o segundo. No caso deste governo, o nível de descentralização não foi maior porque: i) no primeiro mandato, o movimento de descentralização foi parcialmente institucionalizado, no sentido de que o cargo de ministro Extraordinário para Assuntos de Coordenação Política não contou com uma secretaria própria (esteve vinculado à Secretaria-Geral), além do que não possuía a incumbência formal de tratar de questões atinentes aos cargos de confiança e/ou às emendas orçamentárias junto ao Congresso; e ii) no segundo mandato, 
todos os titulares da pasta criada para comandar a coordenação política governamental pertenciam ao partido do presidente, o PSDB.

Por sua vez, o governo Lula atingiu os níveis máximos possíveis de descentralização, quatro (4) pontos. Isto ocorreu em intervalos específicos dos mandatos: entre 2004 e 2005, no primeiro, e entre a segunda metade de 2007 e 2009, ou seja, durante grande parte do segundo. Como se pode observar a partir do Anexo A, nesses períodos a Presidência era constituída com uma estrutura de coordenação política independente da Casa Civil, comandada por titulares filiados a partidos da base (especificamente, PCdoB e PTB), egressos da Câmara dos Deputados e com a competência de tratar de assuntos específicos a emendas orçamentárias.

A descrição feita permite, então, o entendimento de que em ambos os governos há mudanças de cunho descentralizador no âmbito da estrutura de coordenação política da Presidência. Se por um lado é possível observar que essas transformações sugerem, em algum nível, movimentos de concessão de poder do presidente a certos partidos que compõem a coalizão; por outro lado, é preciso qualificar, em maiores detalhes, quais as repercussões que têm para: i) o controle do presidente sobre a condução da articulação política com sua coalizão partidária e, ainda, em termos gerais; e ii) o entendimento a respeito das relações entre os poderes no Brasil. Estes pontos serão discutidos nas considerações finais.

\section{Apontamentos finais}

Com base no que foi apresentado e descrito, pode-se identificar que ao longo dos governos de Fernando Henrique (1995-2002) e Lula (2003-2010) houve a formalização e organização de um arranjo institucional específico na estrutura da Presidência da República com a finalidade de promover a articulação e coordenação política do governo junto ao Congresso Nacional, parlamentares, partidos e, ainda, com os estados e municípios. Observou-se que no início dos respectivos mandatos a estrutura e as atribuições que compunham este arranjo integravam a Casa Civil e que no decorrer do tempo foi criada uma secretaria presidencial exclusiva para a qual se transferiu o arranjo responsável pela coordenação política. 
No mandato de Fernando Henrique, essa mudança institucional ocorreu no primeiro ano do segundo governo (1999), embora em 1996 já tenha havido um movimento em direção de descentralizar o comando da articulação política da Presidência por meio da criação do cargo de ministro Extraordinário para a Coordenação de Assuntos Políticos. Por sua vez, no mandato de Lula, a criação de uma Secretaria de Coordenação Política deu-se no início do segundo ano do primeiro mandato (2004). No quadro que compõe o Anexo A estão expostas todas as trocas de titularidade relativas à estrutura de coordenação política da Presidência, nos governos de Fernando Henrique e Lula da Silva.

Ao que se pode aventar, o principal objetivo com a criação de uma secretaria exclusiva para a coordenação política seria instituir um canal de interlocução e articulação direto e exclusivo da Presidência (e, logo, do presidente) com instituições e atores políticos, que prontamente recolhesse e negociasse as demandas feitas, de modo geral, pelos partidos da coalizão, como contrapartida ao apoio ao governo no Legislativo. Assim, a princípio, a secretaria dedicada à coordenação política constituirse-ia em um canal permanente de contato da Presidência com a base aliada com vistas a negociar, acertar compromissos e, principalmente, intermediar os pedidos e pressões de partidos, parlamentares e demais autoridades da coalizão ao presidente, em troca de apoio legislativo.

Considerando-se que as demandas e pressões da coalizão girariam em torno de cargos de confiança na burocracia federal e de emendas orçamentárias, podese observar que formalmente (i) a partir de 1999, no governo Fernando Henrique, a Subchefia de Assuntos Parlamentares da Secretaria-Geral esteve incumbida de controlar as indicações para provimento dos cargos de confiança da administração federal e que em 2003, nos primeiros dias do governo Lula, esta atribuição foi transferida para a Casa Civil, permanecendo como uma prerrogativa deste órgão até o encerramento dos mandatos do presidente Lula; (ii) a Casa Civil acumulou ainda a partir de 2003 a incumbência praticar os atos de provimento (nomeação formal) dos altos cargos de DAS da burocracia federal; (iii) a Secretaria de Coordenação Política / Relações Institucionais no governo Lula foi encarregada de intermediar junto aos órgãos da administração pública federal, partidos e políticos as negociações para execução da emendas orçamentárias dos parlamentares. 
No caso da SRI, vigente no governo Lula, a despeito de se constituir como um canal de interlocução da Presidência com o Congresso e, precisamente, com os membros da coalizão, possivelmente não estaria ao nível desta secretaria a aprovação, veto e mais precisamente a decisão final sobre o atendimento de demandas relativas às emendas parlamentares. O regulamento que trata desta função é claro ao dispor que a SRI tem, no limite, a competência de recomendar aos órgãos e entidades da administração federal a execução de emendas parlamentares ${ }^{16}$.

Por outro lado, no que concerne ao provimento de cargos de confiança da burocracia federal, a Casa Civil passou a reunir, a partir do governo Lula, um conjunto de atribuições que lhe conferem prerrogativas no processo de preenchimento destes cargos. Compete ao órgão, precisamente, controlar as indicações para os cargos, bem como realizar o seu provimento, ao assinar as portarias de nomeação. Em última instância, a Casa Civil pode, no exercício de suas funções formais, autorizar e/ou vetar as indicações que recebe para ocupação de postos na burocracia.

Esses detalhes revelam que as novas secretarias incumbidas da coordenação política governamental, nos dois governos, não tinham a autonomia ou, formalmente, o controle de dispor sobre os recursos negociados com a coalizão. É possível dizer que estas secretarias tornaram-se a porta de entrada destas demandas no âmbito da Presidência, mas não estaria em nível de suas respectivas competências a aprovação, veto, bem como a repartição destas demandas.

Essas especificidades, no entanto, não podem ofuscar as percepções gerais as quais este trabalho chegou. Afinal, os níveis de controle do presidente sobre os arranjos de coordenação política do seu governo, principalmente nos momentos de reestruturação dos órgãos e funções da Presidência, foram aqui mensurados considerando também outras variáveis. Os detalhes apresentados evidenciam, por sua vez, as teias de controle do presidente mesmo nos atos de descentralização do poder. Serão necessários novos estudos que investiguem a efetividade desses arranjos de coordenação política da Presidência, desvelando, principalmente, como se relacionam com os demais órgãos de assessoramento do presidente, notadamente com a Casa Civil, e com as lideranças do Congresso Nacional e dos partidos que compõem a coalizão. Esses são os objetivos de pesquisas já em curso.

$\mathbf{1 6}$ Ver Decreto 6.207, art. $6^{\circ}$ (BRASIL, 2007). 


\section{Referências}

ABRANCHES, S. Presidencialismo de coalizão: o dilema institucional brasileiro. Dados, v. 31, n. 1, p. 5-34, 1988.

AMORIM NETO, O. Formação de gabinetes presidenciais no Brasil: coalizão versus cooptação. Nova Economia, v. 4, n. 1, p. 9-34, 1994.

AMORIM NETO, O. O Gabinetes presidenciais, ciclos eleitorais e disciplina legislativa no Brasil. Dados, v. 43, n. 3, p. 479-519, 2000.

AMORIM NETO, O.; SANTOS, F. A conexão presidencial: facções pró e antigoverno e disciplina partidária no Brasil. Dados, v. 44, n. 2, p. 291-321, 2001. http://dx.doi.org/10.1590/S001152582001000200003.

AMORIM NETO, O.; TAFNER, P. Governos de coalizão e mecanismos de alarme de incêndio no controle legislativo das medidas provisórias. Dados, v. 45, n. 1, p. 5-38, 2002.

ANDRADE, R. C. (Ed.) Processo de Governo no Município e no Estado: uma análise a partir de São Paulo. São Paulo: EDUSP, 1998.

BRASIL. Decreto no 92.400, de 19 de fevereiro de 1986. Aprova o regimento do Gabinete Civil da Presidência da República e dá outras providências. Diário Oficial da União, Brasília, 19 fev. 1986.

BRASIL. Emenda constitucional no 32, de 11 de setembro de 2001. Altera dispositivos dos Arts. 48, 57, 61, 62, 64, 66, 84, 88 e 246 da Constituição Federal, e dá outras providências. Diário Oficial da União, Brasília, 12 set. 2001.

BRASIL. Decreto n 4.451, de 31 de outubro de 2002. Aprova a Estrutura Regimental e o Quadro Demonstrativo dos Cargos em Comissão da Secretaria-Geral da Presidência da República, e dá outras providências. Diário Oficial da União, Brasília, 4 nov. 2002.

BRASIL. Decreto no 6.207, de 18 de setembro de 2007. Aprova a Estrutura Regimental e o Quadro Demonstrativo dos Cargos em Comissão da Secretaria de Relações Institucionais da Presidência da República, e dá outras providências. Diário Oficial da União, Brasília, 19 set. 2007.

BURKE, J. The Institutional presidency. Baltimore: Johns Hopkins University, 1992.

FIGUEIREDO, A. Resenha de estudos sobre o Executivo. Revista do Serviço Público, v. 55, n. 1-2, p. 5-48, 2004.

FIGUEIREDO, A. Coalition government in the Brazilian democracy. Brazilian Political Science Review, v. 1, n. 2, p. 182-216, 2007.

FIGUEIREDO, A.; LIMONGI, F. O Processo Legislativo e a Produção Legal no Congresso PósConstituinte. Novos Estudos CEBRAP, v. 38, p. 24-37, 1994.

FIGUEIREDO, A.; LIMONGI, F. O. Congresso e as medidas provisórias: abdicação ou delegação. Novos Estudos CEBRAP, v. 47, p. 127-154, 1997. 
FIGUEIREDO, A.; LIMONGI, F. Executivo e Legislativo na Nova Ordem Constitucional. Rio de Janeiro: FGV Editora, 2001.

FIGUEIREDO, A.; LIMONGI, F. Instituições políticas e governabilidade: desempenho do governo e apoio legislativo na democracia brasileira. In: MELO, C. R.; SÁEZ, M. A. (Ed.). A Democracia brasileira: balanços e perspectivas para o século XX. Belo Horizonte: Editora UFMG, 2007.

HALL, P.; TAYLOR, R. As três versões do neo-institucionalismo. Lua Nova, n. 58, p. 225-255, 2003.

HART, J. The Presidential branch. New York: Chatham House, 1995.

KING, A. Executives; In: POLSBY, N. W.; GREENSTEIN, F. I. (Ed.). Handbook of Political Science. Reading: Addison Wesley, 1975.

LAMEIRÃO, C. O papel da Presidência na gestão da coordenação política governamental: arranjos e dinâmicas de poder com a coalizão (1995-2010). Brasília: IPEA, 2015a. (Texto para Discussão, 2041).

LAMEIRÃO, C. Os Níveis de controle da Presidência sobre a coordenação política governamental e a coalizão partidária (1995-2010). In: LOPEZ, F. (Ed.). Cargos de confiança no presidencialismo de coalizão brasileiro. Brasília: IPEA, 2015b.

LINZ, J. The Perils of Presidentialism. Journal of Democracy, v. 1, n. 1, p. 51-69, 1990.

MAINWARING, S. Democracia presidencialista multipartidária: o caso do Brasil. Lua Nova, v. 28-29, p. 21-74, 1993.

MELO, C. R.; ANASTASIA, F. A reforma da previdência em dois tempos. Dados, v. 48, n. 2, p. 301 332, 2005. http://dx.doi.org/10.1590/S0011-52582005000200003.

MENEGUELLO, R. Partidos e governos no Brasil contemporâneo (1985-1997). São Paulo: Paz e Terra, 1998.

MOE, T. The politicized presidency. In: CHUBB, J.; PETERSON, P. (Ed.). The new direction in American politics. Washington: Brooking, 1985.

MOE, T. Political Institutions: The Neglected Side of the Story. Journal of Law Economics and Organization, v.6, n. 6, p. 213-254, 1990. http://dx.doi.org/10.1093/jleo/6.special_issue.213.

MOE, T. Presidents, institutions, and theory. In: EDWARDS III, G. C.; KESSEL, J. H.; ROCKMAN, B. A. (Ed.). Researching the presidency: vital questions, new approaches. Pittsburgh: University of Pittsburgh Press, 1993.

MOISÉS, J. A. (Ed.). O papel do Congresso Nacional no presidencialismo de coalizão. Rio de Janeiro: Konrad Adenauer Stiftung, 2011.

NEUSTADT, R. Poder presidencial e os presidentes modernos. Brasília: ENAP, 2008. Tradução brasileira.

NICOLAU, J. Disciplina Partidária e Base Parlamentar na Câmara dos Deputados no Primeiro Governo Fernando Henrique Cardoso (1995-1998). Dados, v. 43, n. 4, p. 709-736, 2000. http://dx.doi.org/10.1590/S0011-52582000000400004.

NORTH, D. Institutions, institutional change, and economic performance. Cambridge: Cambridge University Press, 1990. 
PALERMO, V. Como se governa o Brasil? O debate sobre instituições políticas e gestão de governo. Dados, v. 43, n. 3, p. 521-557, 2000. http://dx.doi.org/10.1590/S0011-52582000000300004. PEREIRA, C:; MUELLER, B. Uma teoria da preponderância do Executivo: o sistema de comissões no legislativo brasileiro. Revista Brasileira de Ciencias Sociais, v. 15, n. 43, p. 45-67, 2000. http:// dx.doi.org/10.1590/S0102-69092000000200004.

PESSANHA, C. Relações entre os poderes Executivo e Legislativo no Brasil: 1946-1994. Tese (Doutorado)Universidade de São Paulo, São Paulo, 1997.

RASGADALE, L.;THEIS, J. The Institutionalization of the American Presidency, 1924-1992. American Journal of Political Science, v. 41, p. 121-139, 1997.

SALUM JUNIOR, B.; CASARÕES, G. S. P. O impeachment do presidente Collor: a literatura e o processo. Lua Nova, n. 82, p. 163-200, 2011.

SANTOS, F. Patronagem e poder de agenda na política brasileira. Dados, v. 40, n. 3, p. 465-492, 1997.

SANTOS, F. Instituições eleitorais e desempenho do presidencialismo no Brasil. Dados, v. 42, n. 1, p. 111-138, 1999. http://dx.doi.org/10.1590/S0011-52581999000100006.

Recebido: 10 out., 2016 Aceito: 02 jan., 2017 


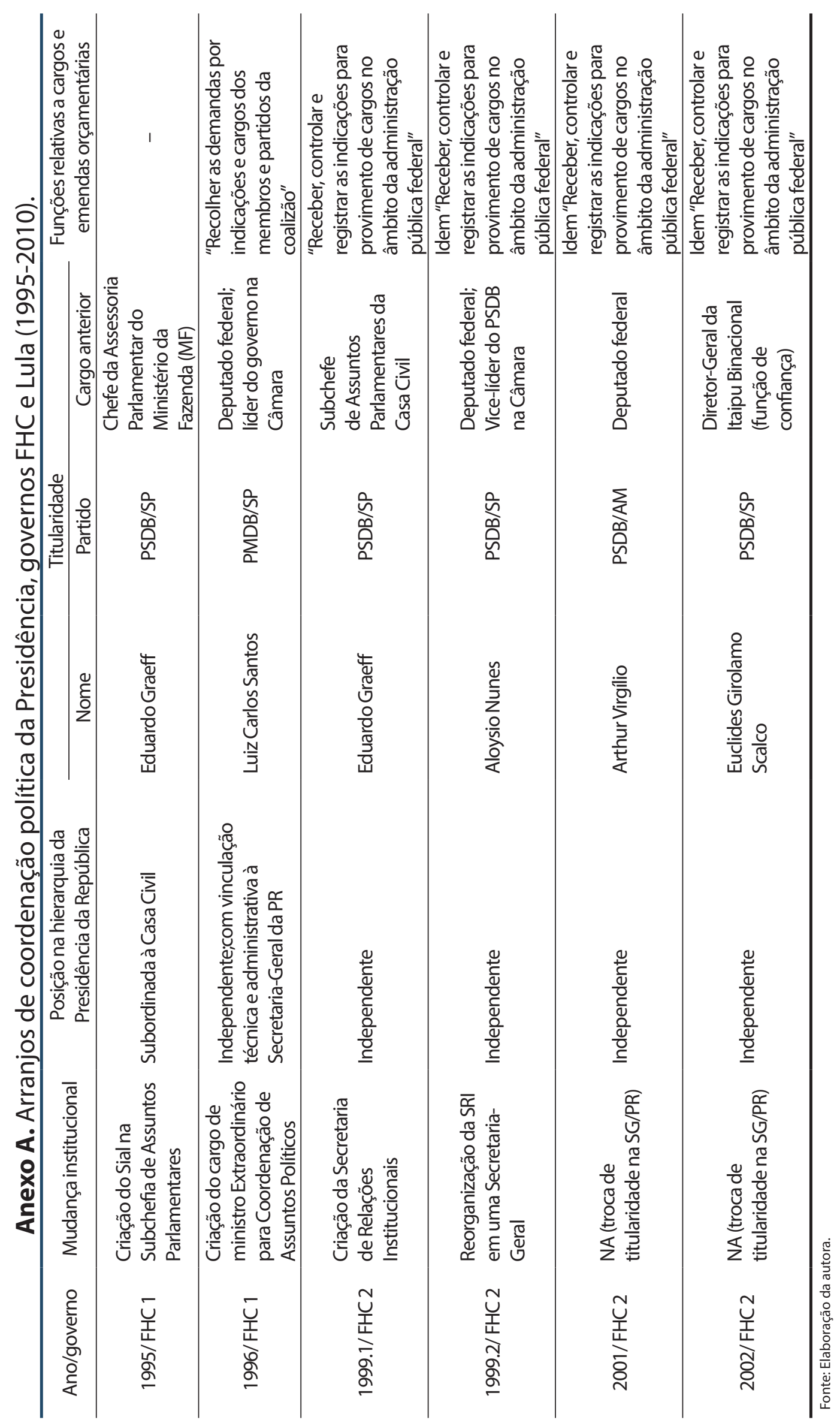




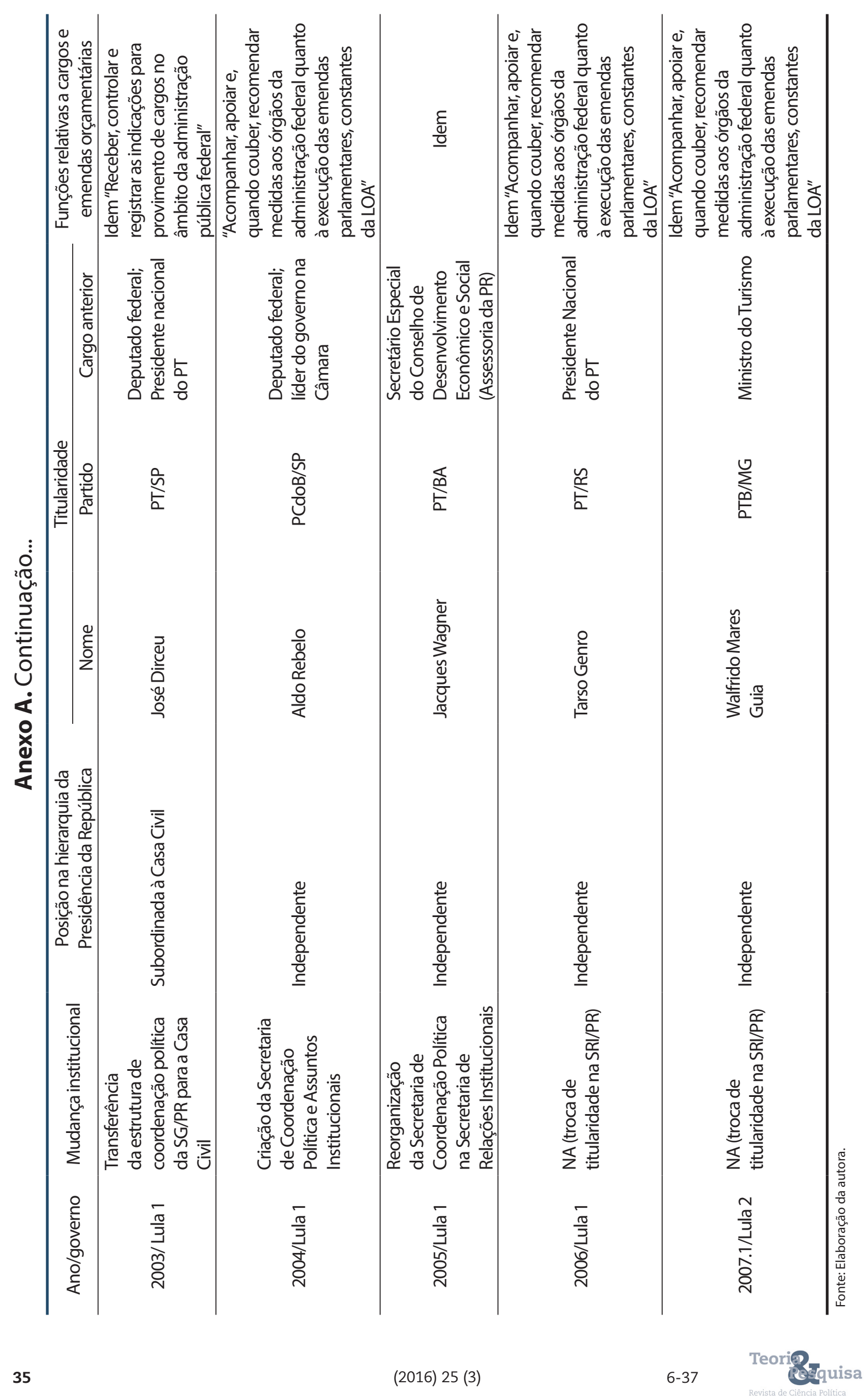




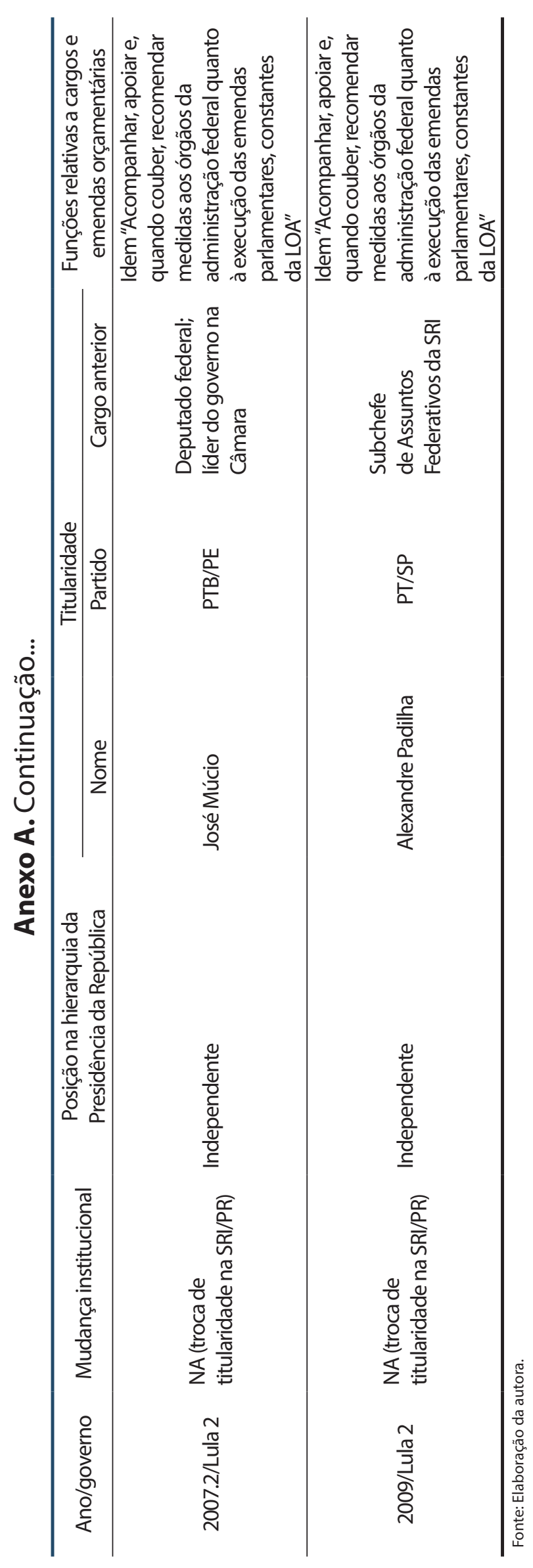


Anexo B. Distribuição por período de governo da pontuação referente às variáveis que medem os níveis de centralização/descentralização dos arranjos de coordenação política da Presidência (referência para o Gráfico 1).

\begin{tabular}{|c|c|c|c|c|c|}
\hline Período & V1 & V2 & V3 & V4 & Total \\
\hline 1995/FHC 1 & 0 & 0 & 0 & 0 & 0 \\
\hline 1996/FHC 1 & 0,5 & 1 & 1 & 0,5 & 3 \\
\hline 1999.1/FHC 2 & 1 & 0 & 0 & 1 & 2 \\
\hline 1999.2/FHC 2 & 1 & 0 & 1 & 1 & 3 \\
\hline 2001/FHC 2 & 1 & 0 & 1 & 1 & 3 \\
\hline 2002/FHC 2 & 1 & 0 & 0 & 1 & 2 \\
\hline 2003/Lula 1 & 0 & 0 & 0 & 1 & 1 \\
\hline 2004/Lula 1 & 1 & 1 & 1 & 1 & 4 \\
\hline 2005/Lula 1 & 1 & 0 & 0 & 1 & 2 \\
\hline 2006/Lula 1 & 1 & 0 & 0 & 1 & 2 \\
\hline 2007.1/Lula 2 & 1 & 1 & 0 & 1 & 3 \\
\hline 2007.2/Lula 2 & 1 & 1 & 1 & 1 & 4 \\
\hline 2009/Lula 2 & 1 & 0 & 0 & 1 & 2 \\
\hline
\end{tabular}

